\title{
Focused library of phenyl-fused macrocyclic amidinoureas as antifungal agents
}

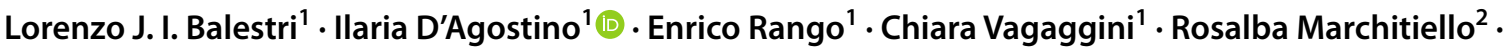 \\ Melinda Mariotti ${ }^{2} \cdot$ Alexandru Casian $^{1}$ - Davide Deodato ${ }^{1}$. Giuseppina I. Truglio ${ }^{1}$ - Francesco Orofino ${ }^{1}$. \\ Maurizio Sanguinetti ${ }^{2,3} \cdot$ Francesca Bugli $^{2,3} \cdot$ Lorenzo Botta $^{4,5}$. Elena Dreassi ${ }^{1}$ (D)
}

Received: 3 December 2021 / Accepted: 13 January 2022 / Published online: 10 February 2022

(c) The Author(s), under exclusive licence to Springer Nature Switzerland AG 2022

\begin{abstract}
The rise of antimicrobial-resistant phenotypes and the spread of the global pandemic of COVID-19 are worsening the outcomes of hospitalized patients for invasive fungal infections. Among them, candidiases are seriously worrying, especially since the currently available drug armamentarium is extremely limited. We recently reported a new class of macrocyclic amidinoureas bearing a guanidino tail as promising antifungal agents. Herein, we present the design and synthesis of a focused library of seven derivatives of macrocyclic amidinoureas, bearing a second phenyl ring fused with the core. Biological activity evaluation shows an interesting antifungal profile for some compounds, resulting to be active on a large panel of Candida spp. and C. neoformans. PAMPA experiments for representative compounds of the series revealed a low passive diffusion, suggesting a membrane-based mechanism of action or the involvement of active transport systems. Also, compounds were found not toxic at high concentrations, as assessed through MTT assays.
\end{abstract}

\section{Graphical abstract}

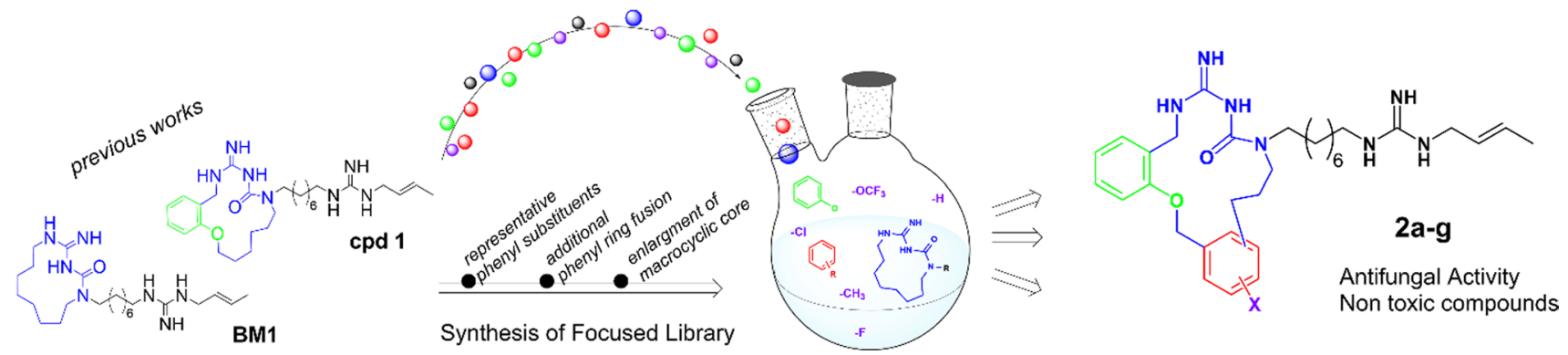

Keywords Amidinourea $\cdot$ Antifungal agents $\cdot$ Candida $\cdot$ Cryptococcus $\cdot$ Macrocycles $\cdot$ PAMPA

Lorenzo J.I. Balestri and Ilaria D'Agostino have contributed equally to the work.

This work is dedicated to Prof. Maurizio Botta, whose hard work and strong devotion to medicinal chemistry research were and still continue to be a source of inspiration for students and researchers.

Elena Dreassi

elena.dreassi@unisi.it

Extended author information available on the last page of the article

\section{Introduction}

Nowadays, the burden of systemic fungal infections is threatening public health. Numbers speak for themselves: annually, more than 150 million people are estimated to suffer from fungal diseases, resulting in a considerable negative impact on their life [1]. Invasive fungal infections (IFIs) are among the most common nosocomial infections, [2] killing up to 1.5 million people each year [3]. IFIs are related to severe illness and high mortality [4-6] in patients with immunocompromised conditions. Moreover, the global 

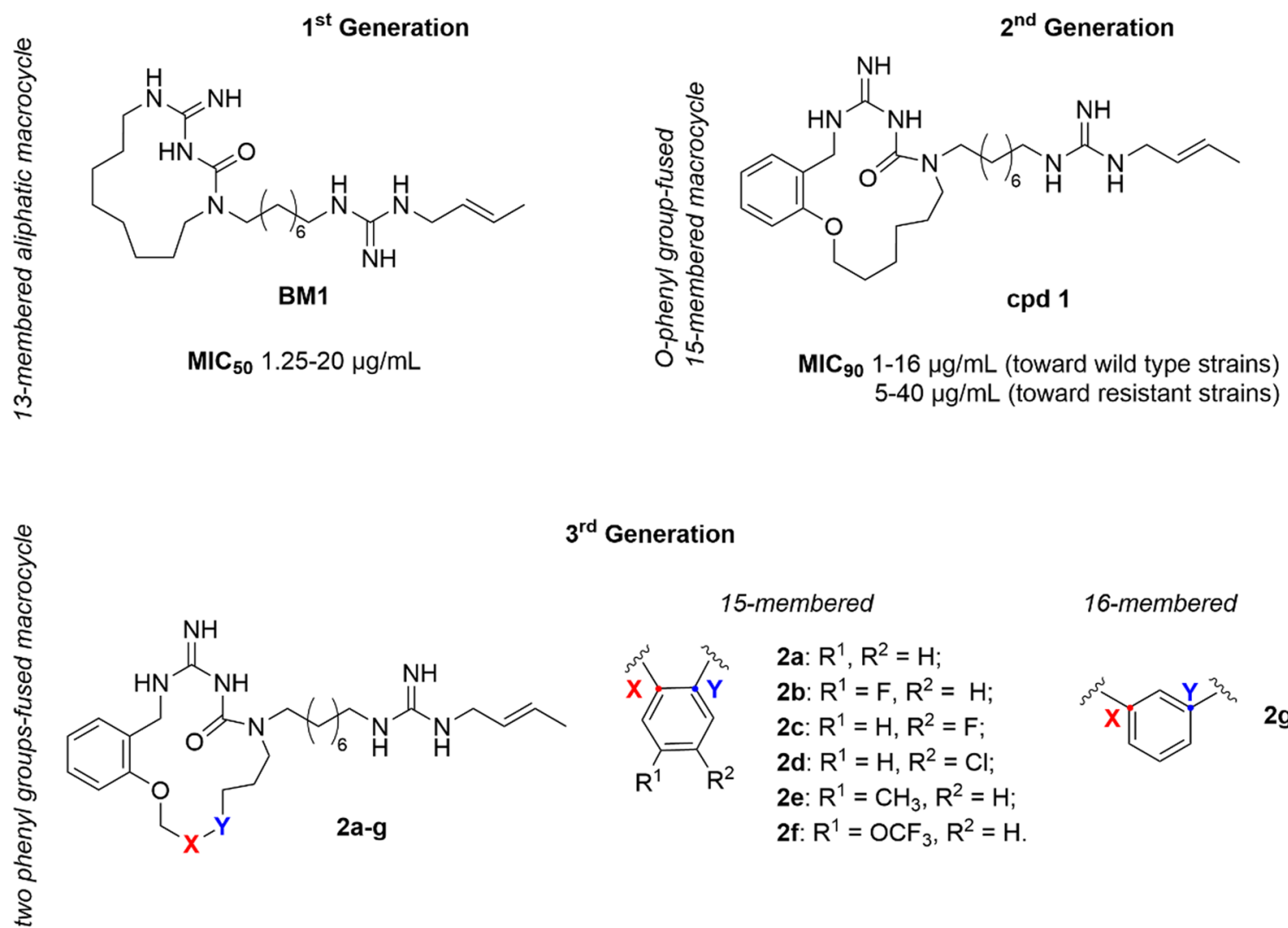

$3^{\text {rd }}$ Generation

Fig. 1 Structure of BM1, compound 1, and derivatives $\mathbf{2 a - g}$ described in this paper with MIC ranges against Candida spp. strains

emergency caused by SARS-CoV-2 worsened the scenario, leading affected people to intubation, mechanical ventilation, and long-term hospitalization that increase the susceptibility to the development of fungal infections [7-9]

Candida species are responsible for nearly half of IFIs $[10,11]$. The most predominant pathogenic strain in bloodstream infections is $C$. albicans. However, recently, diseases caused by non-albicans Candida (NAC) species are increasing in concern [12]. Currently available treatments are mainly represented by azoles, the only orally available class in clinics. Unfortunately, C. krusei, C. auris, and $C$. glabrata, belonging to NAC species, are characterized by a low intrinsic susceptibility to these antifungals and are highly prone to develop resistomes [10]. Moreover, $C$. glabrata displayed a high capacity to form biofilms on artificial devices and epithelial surfaces, leading to a reduction in the drug absorption and consequent decreases in the treatment efficacy [13-15].

Besides Candida species, Cryptococcus neoformans is highly invasive in humans, causing life-threatening meningitis [16], especially in resource-limited regions where treatments of choice based on amphotericin B and 5-flucytosine are not available since too expensive [17].

However, the clinically available antifungal arsenal is still limited to old drug classes, and the more recently developed, the echinocandins, can be traced back to the early 2000s [13, $15,17]$. Only one drug candidate, Fosmanogepix, a broadspectrum antifungal agent, is endowed with an innovative mode of action (MoA), but it is still in clinical trials [18]. Furthermore, no vaccine has still received the food and drug administration (FDA) approval to date. Thus, in this frame, the need for new antifungal agents is pressing to address the high mortality risk of IFIs.

In the last decades, we reported the discovery of a new class of non-azole antifungal agents endowed with an amidinourea macrocyclic scaffold bearing a guanidino tail. The hit compound of the series BM1 (Figure 1) showed antifungal activity with minimum inhibitory concentration $\left(\mathrm{MIC}_{50}\right)$ values ranging from 1.25 to $20 \mu \mathrm{g} / \mathrm{mL}$ against several Candida spp. strains [19-21]. Moreover, it displayed an interesting in vitro and in vivo ADMET profile, even if a limited passive diffusion was highlighted in the previously reported parallel artificial permeability assay (PAMPA) [22].

A small library of derivatives was designed by modifying both the macrocyclic core and the lateral guanidino tail. In particular, the 13-membered macrocyclic portion was enlarged up to 15 carbon atoms and an $O$-phenyl group was fused with it, resulting in a remarkable inhibitory activity against representative Candida spp. strains, including some drug-resistant clinical isolates [19-21]. Compound 1 
(Figure 1) emerged as a good candidate for further studies, exhibiting an enhanced activity against all the tested Candida strains $\left(\mathrm{MIC}_{90}\right.$ values ranging from 1 to $40 \mu \mathrm{g} / \mathrm{mL}$ ) and a more lipophilic macrocyclic scaffold due to the introduction of the $O$-phenyl group. Indeed, this chemical modification was expected to favor the establishment of additional interactions with putative targets through $\pi$-stacking and enhance the compound membrane permeability [20].

As regards the MoA of the amidinoureas class, it is still under investigation, however, in-depth studies seem to confirm an intracellular accumulation of these derivatives [21] and specific interaction with cell structures such as receptors or enzymes, as found through the previously described in silico target fishing protocol [23]. However, what we expect for amidinoureas is an innovative MoA, not shared with current antifungals, since suggested by the notable activity profile found in drug-resistant fungal strains, especially those overexpressing CDR efflux pumps [21].

In order to further explore the chemical space of the macrocyclic core, derivatives with an additional phenyl group were designed. In particular, we synthesized $\mathbf{2 a}$, characterized by a 15-membered macrocycle in which the additional phenyl ring is fused with the macrocycle in ortho-position and $\mathbf{2 g}$ in which it is in meta-position, generating a 16-membered ring (Figure 1). Then, 2b-f (Figure 1), surrounded by some representative electron-withdrawing and electrondonating groups, were prepared to gain an understanding of how they could affect the antifungal activity. Also, PAMPA experiments of compounds $\mathbf{1}$ and $\mathbf{2 a - f}$ were performed to assess the impact of their larger core on membrane permeability, since clogP values are increased with respect to BM1, as calculated by SwissADME tool [24] (data not shown).

\section{Results and discussion}

\section{Chemistry}

The previously published synthetic approach [20] was adapted and optimized to prepare compounds $\mathbf{2 a - g}$. The synthesis of compounds $\mathbf{2} \mathbf{a}-\mathbf{f}$ and $\mathbf{2} \mathbf{g}$ followed the same reaction steps by using different constitutional isomers as key intermediates: the $o$-vinylated derivatives 6a-f (Scheme 1) and the $m$-vinylated one $\mathbf{6 g}$ (Scheme 2).

The preparation of compounds $\mathbf{6 a - f}$ started from the appropriately substituted 2-iodobenzoic acids (a-f) that were first reduced to benzyl alcohols 3a-f. Then, the hydroxy group of 3a-f was converted into a better leaving group, furnishing chlorides $\mathbf{4 a - f}$. The reaction was carried out in mild conditions with tosyl chloride, dimethylaminopyridine, and triethylamine (TEA) due to the co-presence of the more reactive iodine atom in the starting materials 3a-f [25]. Then, 4a-f were reacted with salicylaldehyde to furnish the phenyl ethers 5a-f. Finally, the palladium-catalyzed coupling with a vinyl stannane led to derivatives $\mathbf{6 a - f}$ according to Stille conditions. Aldehydes $\mathbf{6 a - f}$ were first converted into aldoximes 7a-f and then reduced to benzyl amines 8a-f via zinc-mediated hydrogenation. Derivatives 9a-f were finally achieved by guanylating the primary amine moiety with $N, N$ '-Di-Boc-1H-pyrazole-1-carboxamidine [26, 27]. The primary amine belonging to the previously described linker 10 [20] was reacted with the diBoc-guanidino moiety of 9a-f, furnishing tert-butoxycarbonyl (Boc)-protected amidinoureas 11a-f [28]. The latter compounds were endowed with two olefin groups, used as substrates for a ring-closing metathesis. To obtain macrocycles $\mathbf{1 2 a}-\mathbf{f}$, the second generation Grubb's catalyst was added to a very diluted degassed $\mathrm{CH}_{2} \mathrm{Cl}_{2}$ solution of 11a-f. A palladium-catalyzed hydrogenation led to the simultaneous removal of carboxybenzyl $(\mathrm{Cbz})$ protecting group and olefin reduction, affording free amino functions that were subsequently guanylated by the $N$-crotyl-guanylating agent [19] to yield derivatives 13a-f. In the end, final compounds $\mathbf{2 a - f}$ were obtained as trifluoroacetate salts after Boc-cleavage.

Instead, the meta-vinylated intermediate $\mathbf{6 g}$ was synthesized through Wittig reaction from $m$-xylylene dibromide in only three steps (as summarized in Scheme 2) and followed the above-mentioned synthetic route employed for the isomers 6a-f. The whole synthetic pathway along with the intermediates procedures and characterizations were fully reported in Scheme S 1 and in Supporting Information.

\section{Biological evaluation}

The antifungal activity of the synthesized compounds $\mathbf{2} \mathbf{a}-\mathbf{g}$ was evaluated by determining $\mathrm{MIC}_{90}$ against more than 100 strains belonging to 8 Candida spp. (C. albicans, C. guilliermondii, C. crusei, C. parapsilosis, C. tropicalis, C. kefyr, C. glabrata, and C. lipolytica) and 15 strains of Cryptococcus neoformans isolated from oral, vaginal, anorectal, urine, stool, blood, central venous catheter, and respiratory tract specimen with each strain representing a single isolate from a patient (Table 1).

All the derivatives show improved antifungal activity against almost all the tested strains, except the 16-membered macrocycle $\mathbf{2} \mathbf{g}$ with respect to the hit compound $\mathbf{1}$ (Table 1). The introduction of a second phenyl group in the 15-membered macrocycle proved to significantly enhance the antifungal activity, as evident for compound $\mathbf{2 a}$ which showed lower MIC values with respect to the correspondent mono-phenyl derivative $\mathbf{1}$ against $C$. albicans, $C$. kefyr, $C$. parapsilosis, and $C$. guilliermondii. On the other hand, a complete loss of activity against $C$. lipolytica was noticed for 2a (Table 1). The functionalization of the new phenyl ring with one halogen atom, such as fluorine $(\mathbf{2 b}-\mathbf{c})$ and chlorine 
<smiles>[R]c1cc(I)c(C(=O)O)cc1[R]</smiles>
a-f 4a-f<smiles>[R]c1cc(I)c(COc2ccccc2C=O)cc1[R]O</smiles>

5a-f<smiles>[R]c1cc(C=C)c(COc2ccccc2C=O)cc1[R]</smiles>

6a-f

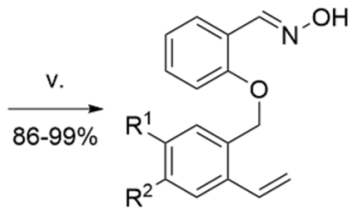

7a-f<smiles>[R]c1cc(C=C)c(COC(C)=CC)cc1[R]</smiles>

$8 a-f$

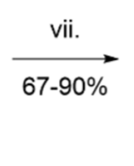

$\rightarrow$<smiles>[R]c1cc(C=C)c(COc2ccccc2CNC(=NC(=O)OCc2ccccc2)NC(C)=O)cc1[R]</smiles>

9a-f

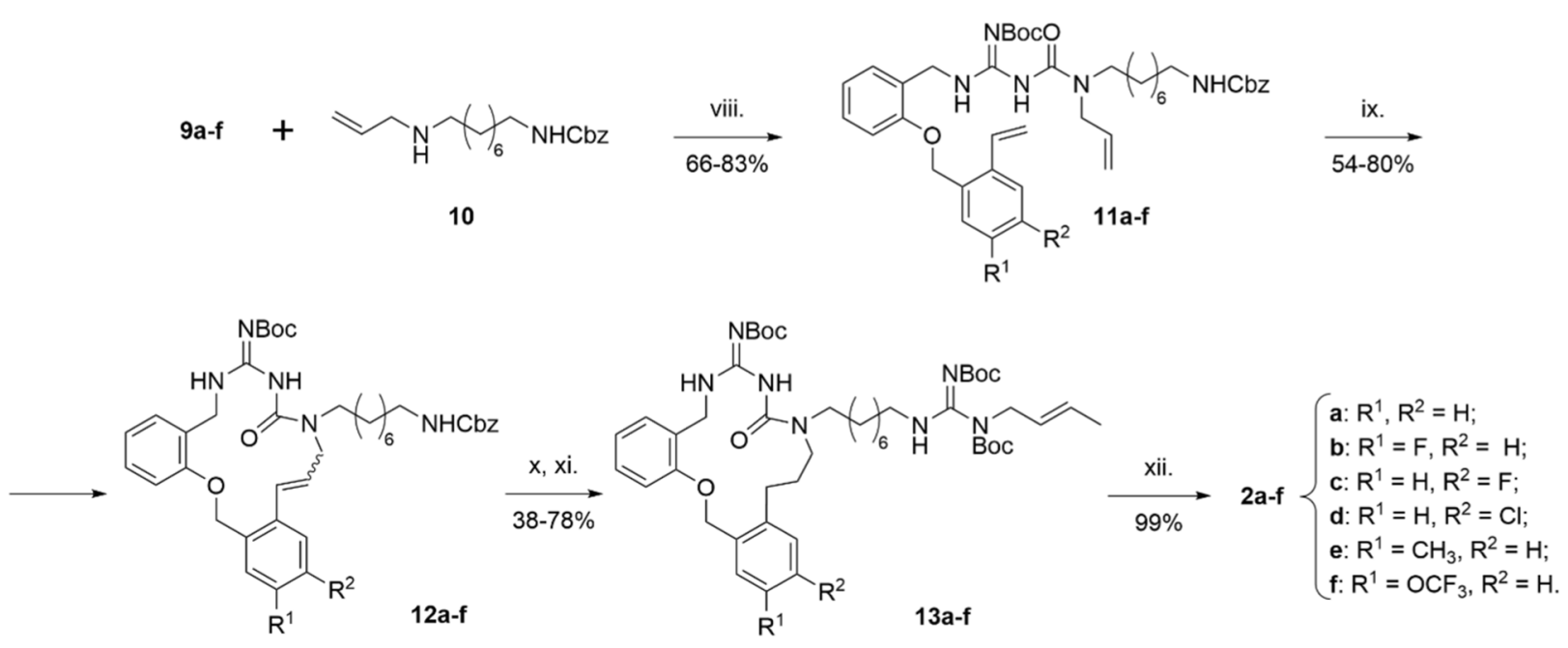

Reagents and conditions: (i.) $\mathrm{BH}_{3}-\mathrm{Me}_{2} \mathrm{~S}$, dry THF, $0{ }^{\circ} \mathrm{C}$-r.t., $12 \mathrm{~h}, \mathrm{~N}_{2}$; (ii.) tosyl chloride, DMAP, dry $\mathrm{TEA}, \mathrm{dry} \mathrm{CH}_{2} \mathrm{Cl}_{2}, 0^{\circ} \mathrm{Cr}$. t., 16 h, $\mathrm{N}_{2}$; (iii.) salicylaldehyde, $\mathrm{K}_{2} \mathrm{CO}_{3}, \mathrm{Nal}, \mathrm{CH}_{3} \mathrm{CN}$, reflux, 16 h; (ii.) tributyl(vinyl)tin, $\mathrm{Pd}(\mathrm{OAc}) 2, \mathrm{PPh}_{3}, \mathrm{dry}$ THF, reflux, 16 h, N2; (v.) $\mathrm{NH}_{2} \mathrm{OH}^{*} \mathrm{HCl}$, pyridine, EtOH, reflux, 3 h; (vi.) Zn dust, $2 \mathrm{~N} \mathrm{HCl}$, THF, reflux, 4 h; (vii.) $N$, $N$ '-Di-Boc- $1 H$-pyrazole1-carboxamidine, DIPEA, THF, r. t., 16 h; (viii.) dry TEA, dry THF, reflux, 16 h, N2; (ix.) 2nd gen. Grubb's catalyst, degassed dry $\mathrm{CH}_{2} \mathrm{Cl}_{2}$, reflux, 16 h, N2; (x.) H2, 1 atm, Pd/C 10\%, cat. glacial AcOH, $i$-PrOH, r. t., 4 h; (xi.) $N, N$ '-Di-Boc- $N$-crotyl-1H-pyrazole1-carboxamidine, dry DIPEA, dry THF, reflux, 12 h; (xii.) TFA, $\mathrm{CH}_{2} \mathrm{Cl}_{2}$, r. t., 12 h.

Scheme 1 Synthesis of final compounds $\mathbf{2 a - f}$<smiles>BrCc1cccc(CBr)c1</smiles><smiles></smiles><smiles>C=Cc1cccc(COc2ccccc2C=O)c1</smiles>

$\overrightarrow{8 \text { steps }}$

Reagents and conditions are reported in Supporting Information.

Scheme 2 Synthesis of final compound 2 f. Reagents and conditions are reported in Supporting Information

(2d), resulted in a better activity profile against some $\mathrm{Can}$ dida strains. In fact, the halogenated derivatives $\mathbf{2 b - d}$ exert a strong antifungal activity against $C$. glabrata with MIC values twofold-fourfold lower than $\mathbf{1}$ and $C$. guilliermondii, C. krusei, and C. kefyr (3.12-1.56 $\mu \mathrm{g} / \mathrm{mL})$ and comparable activities to compound $\mathbf{1}$ toward $C$. albicans, $C$. tropicalis, and C. parapsilosis (Table 1).

Moreover, the substitutions in C4 and C5 of the second phenyl ring were found to impact similarly the biological activity, as highlighted by the same activity profile of the fluoro-isomers $\mathbf{2 b}$ and $\mathbf{2 c}$. The best compound in terms of activity, $\mathbf{2 d}$, is less active against $C$. lipolytica than the fluorine derivatives $\mathbf{2 b - c}$ (Table 1). Also, compounds bearing methyl (2e) and trifluoromethoxy (2f) substituents resulted overall active although less strong than halogenated 
Table 1 MICs of derivatives library (2a-g) against representative Candida spp. and C. neoformans strains

\begin{tabular}{lllllllllll}
\hline \multicolumn{10}{c}{ Antifungal activity, $\mathbf{M I C}_{\mathbf{9 0}}[\boldsymbol{\mu g} / \mathbf{m L}]^{\mathbf{a}}$} \\
\hline Fungal strains & $\mathrm{F}$ & BM1 $^{\mathbf{b}}$ & $\mathbf{1}$ & $\mathbf{2 a}$ & $\mathbf{2 b}$ & $\mathbf{2 c}$ & $\mathbf{2 d}$ & $\mathbf{2 e}$ & $\mathbf{2 f}$ & $\mathbf{2} \mathbf{g}$ \\
\hline C. albicans (22) & 2 & 2.5 & 3.12 & 1 & 3.12 & 3.12 & 3.12 & 4 & 2 & 64 \\
C. guilliermondii (10) & 4 & n.d & 12.5 & 4 & 3.12 & 3.12 & 1.56 & 2 & 2 & 128 \\
C. krusei (13) & 256 & 5 & 6.25 & 8 & 3.12 & 3.12 & 1.56 & 2 & 4 & 64 \\
C. parapsilosis (24) & 0.5 & 5 & 3.12 & 1 & 3.12 & 3.12 & 3.12 & 16 & 16 & 64 \\
C. tropicalis (11) & 2 & 1.25 & 1.56 & 8 & 1.56 & 1.56 & 1.56 & 4 & 4 & 64 \\
C. kefyr(10) & 1 & n.d & 6.25 & 2 & 3.12 & 3.12 & 1.56 & 4 & 4 & 32 \\
C. glabrata(26) & 16 & 20 & 25 & 16 & 12.5 & 12.5 & 6.25 & 16 & 16 & 512 \\
C. lipolytica(10) & n.d & n.d & 25 & 256 & 6.25 & 6.25 & 12.5 & 4 & 4 & n.a \\
C. neoformans (15) & 2 & n.d & 6.25 & n.d & 3.12 & 3.12 & 3.12 & 4 & 4 & n.d \\
\hline
\end{tabular}

${ }^{\mathrm{a}} \mathrm{MICs}$ are expressed in $\mu \mathrm{g} / \mathrm{mL}$ as the average values calculated from experiments performed at least in triplicate and determined at $24 \mathrm{~h}$ both visually and spectrophotometrically. $\mathrm{MIC}_{50}=$ Minimum inhibitory concentration required to inhibit the growth of $50 \%$ of organisms. $\mathrm{MIC}_{90}=$ Minimum inhibitory concentration required to inhibit the growth of $90 \%$ of organisms. The number of tested strains per species is reported in parentheses. Fluconazole (F) and BM1 are reported as reference control and reference compound, respectively

n.d.: not determined; n.a.: not active, no activity observed till compound concentration of $256 \mu \mathrm{g} / \mathrm{mL}$

${ }^{\mathrm{b}} \mathrm{MIC}_{50}$ values for BM1 were already reported for some Candida species [20] compounds $\mathbf{2 b}-\mathbf{d}$ (Table 1 ). In the end, derivative $\mathbf{2 g}$, characterized by a 16-membered ring, showed a dramatic loss of activity against all tested species, suggesting the key role of the macrocyclic size for biological activity. These data could confirm our hypothesis of a proteic target since tiny chemical modifications in the structure led to a total or partial loss of antifungal activity (Table 1).

In summary, 15-membered derivatives $\mathbf{2 a - e}$ were found more active than the hit compound $\mathbf{1}$ against most of the fungal strains and, remarkably, active against strains not susceptible to fluconazole, C. glabrata, and C. krusei. As mentioned above, infections from $C$. glabrata are representing a serious threat since it is one of the most resistant fungal species, together with $C$. auris, to the azole drugbased treatments. Moreover, halogenated derivatives $\mathbf{2 b - \mathbf { d }}$ were highlighted as the most active compound of the series, showing also an inhibitory activity against $C$. neoformans, the pathogenic fungi responsible for fatal meningitis, comparable to that of fluconazole (Table 1).

\section{Cytotoxicity on human fibroblasts}

To evaluate the selectivity of the series, the cytotoxicity profile was assessed by determining the $\mathrm{CC}_{50}$ value on Normal Human Dermal Fibroblast (FIBRO) cell line through the MTT assay. Compounds $\mathbf{2 a}, \mathbf{2} \mathbf{b}$, and $\mathbf{2 d}$ were selected as the most interesting representatives of the library in terms of antifungal activity. As shown in Table 2, after $24 \mathrm{~h}, \mathbf{2 a}$ and $\mathbf{2 b}$ were found to be not cytotoxic at high concentrations $\left(\mathrm{CC}_{50}>100 \mu \mathrm{g} / \mathrm{mL}\right)$, while $2 \mathrm{~d}$ a lower $\mathrm{CC}_{50}(38.50 \mu \mathrm{g} / \mathrm{mL})$, still maintaining a good selectivity index $(>12)$ for almost all the tested strains.

\section{PAMPA experiments}

PAMPA was performed to evaluate if the introduction of an additional phenyl ring into the macrocyclic portion could be useful to gain an enhancement in the membrane permeability via passive diffusion. Thus, compounds $\mathbf{2 a}, \mathbf{2} \mathbf{b}$, and $\mathbf{2 d}$ were selected as representatives of the new series, and the experiment was conducted also on compound $\mathbf{1}$ to make a comparison among the apparent permeability $\left(P_{\mathrm{app}}\right)$ values determined for the aliphatic macrocycle of BM1, the $O$-phenyl-fused macrocycle of $\mathbf{1}$, and the tricycle core of $\mathbf{2}$. All the tested diphenyl derivatives and $\mathbf{1}$ showed very low $P_{\text {app }}$ values (Table 3) close to that reported for BM1,[22] resulting in scarce permeability, and were highly retained from the bilayer, with approximatively $50 \%$ of membrane

Table 2 In vitro cytotoxicity results on FIBRO cells for derivatives 2a, 2b, and 2d

\begin{tabular}{|c|c|c|}
\hline \multirow[b]{2}{*}{ Cpd } & \multicolumn{2}{|c|}{$\mathrm{CC}_{50}$ on FIBRO cell line $[\mu \mathrm{g} / \mathrm{mL} \pm$ S.D. $]$} \\
\hline & $24 \mathrm{~h}$ & $48 \mathrm{~h}$ \\
\hline $\mathbf{2 a}$ & $>100$ & $36.17 \pm 1.86$ \\
\hline $\mathbf{2 b}$ & $>100$ & $24.86 \pm 1.07$ \\
\hline $2 d$ & $38.50 \pm 2.18$ & $25.44 \pm 1.67$ \\
\hline
\end{tabular}


Table 3 PAMPA results for tested compounds

\begin{tabular}{lll}
\hline Cpd & $\begin{array}{l}\text { Papp } \\
{\left[10^{-6} \mathrm{~cm} / \mathrm{sec}\right]}\end{array}$ & $\begin{array}{l}\text { Membrane } \\
\text { retention }(\%)\end{array}$ \\
\hline $\mathbf{1}$ & $<0.01$ & 50.8 \\
2a & $<0.01$ & 55.3 \\
2b & $<0.01$ & 50.6 \\
2d & $<0.01$ & 52.1 \\
Caffeine & 1.84 & 3.2 \\
Chloramphenicol & 0.30 & 26.3 \\
\hline
\end{tabular}

Experiments were performed in duplicate. LC-UV-MS method is described in Experimental section. Caffeine and chloramphenicol are reported as reference compounds

retention percentage. Although the chemical modification led to an increase in lipophilicity, it was not able to affect the passive absorption of these derivatives, as hypothesized. However, the high membrane retention of this class of compounds could be correlated to additional MoAs involving membranes directly or membrane proteins or transporters, as previously demonstrated [21].

\section{Conclusion}

Fungal infections represent one of the global healthy treats to date. Among compounds endowed with antifungal activity, macrocycle amidinoureas emerged for their innovative structure and their potent activity toward most Candida species including some resistant clinical isolates.

In this study, we investigated the insertion of a second ring into the macrocycle core of a previously described derivative $\mathbf{1}$, by synthesizing two isomers, compounds $\mathbf{2 a}$ and $\mathbf{2 b}$, endowed with a 15- and 16-membered cycle, respectively. The chemical modification led to a slightly better biological profile for $\mathbf{2 a}$ and a complete loss of activity for $\mathbf{2 f}$. Also, we functionalized the phenyl ring with some representative electron-withdrawing and donating groups, such as halogen atoms, methyl, and trifluoromethoxy groups. The synthesized derivatives showed promising antifungal activity against a panel of Candida spp. and C. neoformans microorganisms that was found overall stronger than hit compound BM1 and fluconazole. Remarkably, 2b-d emerged as the best derivatives in terms of antifungal activity toward C. glabrata, C. krusei, and C. kefyr, commonly resistant to most of the current treatments and not susceptible to the azole class. We could hypothesize a possible interaction with a specific pharmacological target, such as an enzyme or receptor since tiny modifications in the chemical structure resulted in a significant change in the biological activity. However, in-depth investigation of the MoA of macrocyclic amidinoureas is still ongoing.
Furthermore, three representatives of the series, compounds $\mathbf{2 a}, \mathbf{2 b}$, and $\mathbf{2 d}$, were found low cytotoxic at high concentrations in MTT assays, resulting in a good selectivity index. Also, we checked these compounds for their passive permeability through PAMPA experiments. Although more lipophilic (as calculated by means of SwissADME tool)[24] than hit compound $\mathbf{1}$, they showed low passive adsorption comparable to that of compound $\mathbf{1}$.

In summary, the series described herein was found to exert an interesting antifungal activity, proving the impact of the insertion of the second phenyl ring into the macrocyclic scaffold in the biological profile. These results highlight this tricyclic core of the macrocyclic amidinoureas a putative starting point for the development of a new class of antifungal agents.

\section{Experimental section}

\section{Chemistry}

General Chemistry All commercially available chemicals and solvents were used as purchased. $\mathrm{CH}_{2} \mathrm{Cl}_{2}$ was dried over calcium hydride and tetrahydrofuran (THF) was dried over sodium and benzophenone before use. Degassed dry $\mathrm{CH}_{2} \mathrm{Cl}_{2}$ was prepared from freshly dried $\mathrm{CH}_{2} \mathrm{Cl}_{2}$ via three or more freeze-pump-thaw cycles. Dry DIPEA was purchased from Merck. Dry TEA was dried over KOH and distilled under nitrogen atmosphere. Anhydrous reactions were performed into flame-dried glassware after three cycles of vacuum/dry nitrogen and were run under a positive pressure of dry nitrogen. Chromatographic separations were performed on columns packed with silica gel (230-400 mesh, for flash technique). TLCs were visualized under UV light and stained with ninhydrin, bromocresol green, or basic permanganate stains. ${ }^{1} \mathrm{H}$ NMR and ${ }^{13} \mathrm{C}$ NMR were recorded on a Bruker Avance 400 spectrometer at $400 \mathrm{MHz}$ and $100 \mathrm{MHz}$, respectively. Spectra are reported in parts per million ( $\delta$ scale) and internally referenced to the $\mathrm{CDCl}_{3}$ and $\mathrm{CD}_{3} \mathrm{OD}$ signal, respectively at $\delta 7.26$ and $3.31 \mathrm{ppm}$. Chemical shifts for carbon are reported in parts per million ( $\delta$ scale) and referenced to the carbon resonances of the solvent $\left(\mathrm{CDCl}_{3}\right.$ at $\delta 77.0$ and $\mathrm{CD}_{3} \mathrm{OD}$ at $\delta 49.0 \mathrm{ppm}$ ). Data are shown as following: chemical shift, multiplicity $(\mathrm{s}=$ singlet, $\mathrm{d}=$ doublet, $\mathrm{t}=$ triplet, $\mathrm{q}=$ quartet, $\mathrm{qi}=$ quintet, $\mathrm{m}=$ multiplet and/or multiplet resonances, bs $=$ broad singlet), coupling constants $(J)$ in Hertz (Hz), and integration. Mass spectra (LCMS (ESI)) were acquired using an Agilent 1100 LC-MSD VL system (G1946C) by direct injection with a $0.4 \mathrm{~mL} / \mathrm{min}$ flow rate using a binary solvent system of $95 / 5 \mathrm{MeOH} / \mathrm{H}_{2} \mathrm{O}$. UV detection was monitored at 221 or $254 \mathrm{~nm}$. Mass spectra were acquired in positive or negative mode scanning over 
the mass range $100-1500 \mathrm{~m} / z$, using a variable fragmentor voltage of $0-70 \mathrm{~V}$.

Determination of purity The purity of final products $(\geq 95 \%)$ was assessed by LC-UV-MS analysis using the protocol reported [29].

\section{Synthetic procedures and characterizations of compound $2 \mathrm{a}$ and its intermediates}

(2-iodophenyl)methanol ( $3 a$ ) To a stirred suspension of 2-iodobenzoic acid $(3.00 \mathrm{~g}, 12.09 \mathrm{mmol})$ in dry THF $(40 \mathrm{~mL})$, borane dimethyl sulfide complex $(3.44 \mathrm{~mL}$, $36.29 \mathrm{mmol}$ ) was added dropwise under $\mathrm{N}_{2}$ atmosphere at $0{ }^{\circ} \mathrm{C}$. Then, the reaction mixture was allowed to gently warm at r.t. and stirred for $12 \mathrm{~h}$. Water and $\mathrm{K}_{2} \mathrm{CO}_{3}$ were carefully added and the mixture was stirred for additional $30 \mathrm{~min}$. Then, the mixture was extracted with AcOEt and washed twice with $1 \mathrm{~N} \mathrm{NaOH}$ and then with brine. The organic layer was dried over anhydrous $\mathrm{Na}_{2} \mathrm{SO}_{4}$, filtered, and evaporated in vacuo to give pure 2-iodobenzyl alcohol 3a as a white solid. Yield: $98 \% .{ }^{1} \mathbf{H}-\mathbf{N M R}\left(400 \mathrm{MHz}, \mathrm{CDCl}_{3}\right) \delta \mathrm{ppm}$ $7.80(\mathrm{~d}, J=8.0 \mathrm{~Hz}, 1 \mathrm{H}), 7.43(\mathrm{~d}, J=7.6 \mathrm{~Hz}, 1 \mathrm{H}), 7.35(\mathrm{t}$, $J=7.2 \mathrm{~Hz}, 1 \mathrm{H}), 6.98(\mathrm{t}, J=8.0 \mathrm{~Hz}, 1 \mathrm{H}), 4.65(\mathrm{~d}, J=5.6 \mathrm{~Hz}$, 2H), $2.49(\mathrm{t}, J=6.0 \mathrm{~Hz}, 1 \mathrm{H}) .{ }^{13} \mathbf{C}-\mathbf{N M R}\left(100 \mathrm{MHz}, \mathrm{CDCl}_{3}\right)$ $\delta \mathrm{ppm} 142.5,139.1,129.2,128.4,128.3,97.3,59.8$.

1-(chloromethyl)-2-iodobenzene ( $4 a$ ) To a stirred solution of $3 \mathbf{a}(2.78 \mathrm{~g}, 11.88 \mathrm{mmol})$ in dry $\mathrm{CH}_{2} \mathrm{Cl}_{2}(80 \mathrm{~mL})$, freshly distilled dry TEA (1.66 mL, $11.88 \mathrm{mmol})$ and DMAP $(1.74 \mathrm{~g}, 14.26 \mathrm{mmol})$ were added under $\mathrm{N}_{2}$ atmosphere at $0{ }^{\circ} \mathrm{C}$. Then, $p$-toluenesulfonyl chloride $(4.07 \mathrm{~g}, 21.38 \mathrm{mmol})$ was added portionwise and the reaction mixture was stirred for additional $30 \mathrm{~min}$ at $0{ }^{\circ} \mathrm{C}$, then at r.t. for $16 \mathrm{~h}$. The solvent was removed by evaporation in vacuo and the crude was purified by flash chromatography on silica gel, eluting with hexane to give compound 4a. Yield: $56 \% .{ }^{1} \mathbf{H}-\mathbf{N M R}$ $\left(400 \mathrm{MHz}, \mathrm{CDCl}_{3}\right) \delta \mathrm{ppm} 7.85(\mathrm{~d}, J=7.6 \mathrm{~Hz}, 1 \mathrm{H}), 7.47$ (d, $J=8 \mathrm{~Hz}, 1 \mathrm{H}), 7.34$ (t, $J=7.2 \mathrm{~Hz}, 1 \mathrm{H}), 6.99(\mathrm{~d}, J=8 \mathrm{~Hz}, 1 \mathrm{H})$, $4.66(\mathrm{~s}, 2 \mathrm{H}) .{ }^{13} \mathrm{C}-\mathrm{NMR}\left(100 \mathrm{MHz}, \mathrm{CDCl}_{3}\right) \delta \mathrm{ppm} 139.8$, 135.6, 129.7, 129.3, 126.7, 96.8, 44.2.

2-[(2-iodophenyl)methoxy]benzaldehyde (5a) To a stirred solution of salicylaldehyde $(0.50 \mathrm{~mL}, 4.69 \mathrm{mmol})$ in $\mathrm{CH}_{3} \mathrm{CN}$ $(10 \mathrm{~mL}), \mathrm{K}_{2} \mathrm{CO}_{3}(710.0 \mathrm{mg}, 5.16 \mathrm{mmol}), \mathrm{NaI}(0.18 \mathrm{~g}$, $1.17 \mathrm{mmol})$, and $4 \mathbf{a}(1.30 \mathrm{~g}, 5.16 \mathrm{mmol})$ were added and the reaction mixture was stirred at reflux for $16 \mathrm{~h}$. After evaporation in vасио, the residue was dissolved in AcOEt, $1 \mathrm{~N}$ $\mathrm{NaOH}$ was added, and the mixture was stirred at r.t. for additional $10 \mathrm{~min}$. Then, the mixture was extracted with AcOEt three times, and the combined organic layers were washed with brine, dried over anhydrous $\mathrm{Na}_{2} \mathrm{SO}_{4}$, filtered, and evaporated in vacuo to give 5a. Yield: $92 \% .{ }^{1} \mathbf{H}-\mathbf{N M R}(400 \mathrm{MHz}$, $\left.\mathrm{CDCl}_{3}\right) \delta$ ppm $10.58(\mathrm{~s}, 1 \mathrm{H}), 7.87$ (t, $\left.J=7.6 \mathrm{~Hz}, 1 \mathrm{H}\right), 7.56$ $(\mathrm{t}, J=7.6 \mathrm{~Hz}, 2 \mathrm{H}), 7.50(\mathrm{~m}, 1 \mathrm{H}), 7.38(\mathrm{t}, J=7.2 \mathrm{~Hz}, 2 \mathrm{H})$, $7.05(\mathrm{~m}, 2 \mathrm{H}), 5.16(\mathrm{~s}, 2 \mathrm{H}) .{ }^{13} \mathrm{C}-\mathrm{NMR}\left(100 \mathrm{MHz}, \mathrm{CDCl}_{3}\right) \delta$ ppm 189.4, 160.8, 142.2,139.5, 135.9, 129.6, 129.2, 128.6, 128.2, 125.3, 121.1, 113.0, 92.9, 67.9.

2-[(2-ethenylphenyl)methoxy]benzaldehyde (6a) To a stirred solution of iododerivative $5 \mathbf{a}(1.11 \mathrm{~g}, 3.28 \mathrm{mmol})$ in dry THF $(46 \mathrm{~mL})$, palladium acetate $(73.0 \mathrm{mg}, 0.33 \mathrm{mmol})$ and triphenylphosphine (172.0 $\mathrm{mg}, 0.66 \mathrm{mmol}$ ) were added under $\mathrm{N}_{2}$ atmosphere. Then, tributyl(vinyl)tin $(1,13 \mathrm{~mL}$, $3.93 \mathrm{mmol}$ ) was added dropwise and the reaction mixture was stirred at reflux for $16 \mathrm{~h}$. After cooling, the mixture was filtered through a plug of celite, and the filtrate was evaporated in vacuo. The residue was diluted with AcOEt, washed with $\mathrm{NaHCO}_{3}$ ss and brine. Then, it was dried over anhydrous $\mathrm{Na}_{2} \mathrm{SO}_{4}$, filtered, and evaporated in vacuo. The crude was purified by flash chromatography on silica gel, eluting with hexane/AcOEt 9:1. Yield: $90 \%$. ${ }^{1}$ H-NMR (400 MHz, $\mathrm{CDCl}_{3}$ ) $\delta \mathrm{ppm} 10.47$ (s, $\left.1 \mathrm{H}\right), 7.85(\mathrm{~d}, J=7.7 \mathrm{~Hz}, 1 \mathrm{H}), 7.55$ $(\mathrm{m}, 2 \mathrm{H}), 7.42(\mathrm{~d}, J=6.8 \mathrm{~Hz}, 1 \mathrm{H}), 7.36(\mathrm{t}, J=7.2 \mathrm{~Hz}, 1 \mathrm{H})$, $7.30(\mathrm{~d}, J=8.0 \mathrm{~Hz}, 1 \mathrm{H}), 7.04(\mathrm{~m}, 2 \mathrm{H}), 6.99(\mathrm{dd}, J=17.2 \mathrm{~Hz}$, $11.2 \mathrm{~Hz}, 1 \mathrm{H}), 5.70(\mathrm{~d}, J=18.0 \mathrm{~Hz}, 1 \mathrm{H}), 5.34(\mathrm{~d}, J=10.8 \mathrm{~Hz}$, 1H), $5.22(\mathrm{~s}, 2 \mathrm{H}) .{ }^{13} \mathrm{C}-\mathrm{NMR}\left(100 \mathrm{MHz}, \mathrm{CDCl}_{3}\right) \delta \mathrm{ppm}$ 189.6, 160.9, 137.2, 135.8, 133.6, 128.8, 128.3, 127.9, 126.2, 125.3, 121.0, 117.0, 113.0, 77.1, 76.8, 68.8.

Aldoxime derivative (7a) To a stirred solution of benzaldehyde 7a (334.0 mg, $1.84 \mathrm{mmol})$ in EtOH $(25 \mathrm{~mL})$, pyridine $(180 \mu \mathrm{L}, 2.21 \mathrm{mmol})$ and hydroxylamine hydrochloride (320.0 mg, $4.6 \mathrm{mmol}$ ) were added. The mixture was stirred at reflux for $3 \mathrm{~h}$. After cooling, the mixture was evaporated in vacuo and the residue was dissolved in AcOEt, washed with brine twice, dried over anhydrous $\mathrm{Na}_{2} \mathrm{SO}_{4}$, filtered, and evaporated in vacuo. Yield: $96 \%$. ${ }^{\mathbf{H}} \mathrm{H}-\mathbf{N M R}(400 \mathrm{MHz}$, $\left.\mathrm{CDCl}_{3}\right) \delta \mathrm{ppm} 8.52(\mathrm{~s}, 1 \mathrm{H}), 8.31(\mathrm{bs}, 1 \mathrm{H}), 7.75(\mathrm{~d}$, $J=8.0 \mathrm{~Hz}, 1 \mathrm{H}), 7.55(\mathrm{~d}, J=7.6 \mathrm{~Hz}, 1 \mathrm{H}), 7.40(\mathrm{~m}, 1 \mathrm{H}), 7.34$ $(\mathrm{m}, 3 \mathrm{H}), 6.95(\mathrm{~m}, 3 \mathrm{H}), 5.69(\mathrm{~d}, J=17.6 \mathrm{~Hz}, 1 \mathrm{H}), 5.34(\mathrm{~d}$, $J=10.8 \mathrm{~Hz}, 1 \mathrm{H}), 5.14$ (s, 2H). ${ }^{\mathbf{1 3}} \mathbf{C}-\mathbf{N M R}\left(100 \mathrm{MHz}, \mathrm{CDCl}_{3}\right)$ $\delta$ ppm 163.5 156.6, 146.3, 137.1, 133.6, 133.1, 131.2, 128.9, 128.6, 127.8, 126.6, 126.1, 121.2, 116.9, 112.5, 68.4. LCMS (ESI) $m / z=276.0[\mathrm{M}+\mathrm{Na}]^{+}, 254.0[\mathrm{M}+\mathrm{H}]^{+}$.

Benzylamino derivative ( $8 a$ ) To a stirred solution of aldoxime 7a $(251.0 \mathrm{mg}, 0.99 \mathrm{mmol})$ in THF $(12 \mathrm{~mL})$, zinc dust $(650.0 \mathrm{mg}, 9.89 \mathrm{mmol})$ and $2 \mathrm{~N} \mathrm{HCl}(5 \mathrm{~mL})$ were added, and the reaction mixture was stirred at reflux for $4 \mathrm{~h}$. After cooling, the mixture was filtered on a plug of celite, and the filtrate was evaporated in vacuo. The residue was dissolved in AcOEt and extracted with $3 \mathrm{~N} \mathrm{HCl}$ three times. Then, the aqueous phase was basified with $\mathrm{K}_{2} \mathrm{CO}_{3}$ and extracted with $\mathrm{CH}_{2} \mathrm{Cl}_{2}$ three times. The combined organic layers were dried over anhydrous $\mathrm{Na}_{2} \mathrm{SO}_{4}$, filtered, and evaporated in vacuo. Compound 8a was obtained without any further purification. Yield: $99 \%$. ${ }^{1}$ H-NMR (400 MHz, CD 3 OD) $\delta \mathrm{ppm} 7.56(\mathrm{~d}, J=7.7 \mathrm{~Hz}$, 1H), 7.42 (d, $J=7.4 \mathrm{~Hz}, 1 \mathrm{H}), 7.34$ (d, $J=7.5 \mathrm{~Hz}, 1 \mathrm{H}), 7.29$ $(\mathrm{d}, J=7.3 \mathrm{~Hz}, 1 \mathrm{H}), 7.23(\mathrm{~d}, J=7.1 \mathrm{~Hz}, 2 \mathrm{H}), 7.46(\mathrm{~m}, 3 \mathrm{H})$, 5.70 (d, $J=17.4 \mathrm{~Hz}, 1 \mathrm{H}), 5.33$ (d, $J=11.0 \mathrm{~Hz}, 1 \mathrm{H}), 5.12$ 
(s, 2H), 3.81 (s, 2H), 1.62 (bs, 2H). ${ }^{13}$ C-NMR (100 MHz, $\left.\mathrm{CD}_{3} \mathrm{OD}\right) \delta \mathrm{ppm} 156.4,137.0,133.8,133.7,131.8,129.3$, $129.2,128.9,128.8,128.5,128.3,128.1,127.9,126.0$, 120.9, 116.6, 111.4, 67.5, 42.1. LCMS (ESI) $m / z=262.1$ $[\mathrm{M}+\mathrm{Na}]^{+}, 240.1[\mathrm{M}+\mathrm{H}]^{+}$.

DiBoc-guanidino derivative ( $9 a$ ) To a stirred solution of primary amine $8 \mathbf{a}(251.0 \mathrm{mg}, 1.05 \mathrm{mmol})$ in THF $(10 \mathrm{~mL})$, $N, N^{\prime}$-Di-Boc-1H-pyrazole-1-carboxamidine (420.2 mg, $1.36 \mathrm{mmol})$ and DIPEA $(90 \mu \mathrm{L}, 0.52 \mathrm{mmol})$ were added. The reaction mixture was stirred at r.t. for $16 \mathrm{~h}$. After cooling, AcOEt was added, and the mixture was washed with water and brine. After drying over anhydrous $\mathrm{Na}_{2} \mathrm{SO}_{4}$, the mixture was filtered and evaporated in vacuo. The crude residue was purified by flash chromatography on silica gel, eluting with hexane/AcOEt 9:1 to give the pure compound 9a. Yield: $78 \%$. ${ }^{\mathbf{1}} \mathbf{H}-\mathbf{N M R}\left(400 \mathrm{MHz}, \mathrm{CDCl}_{3}\right) \delta \mathrm{ppm}$ $11.47(\mathrm{~s}, 1 \mathrm{H}), 8.67(\mathrm{~s}, 1 \mathrm{H}), 7.52(\mathrm{~d}, J=7.5 \mathrm{~Hz}, 1 \mathrm{H}), 7.43$ $(\mathrm{d}, J=7.3 \mathrm{~Hz}, 1 \mathrm{H}), 7.31(\mathrm{t}, J=7.2 \mathrm{~Hz}, 2 \mathrm{H}), 7.25(\mathrm{~m}, 2 \mathrm{H})$, $6.95(\mathrm{~m}, 3 \mathrm{H}), 5.66(\mathrm{~d}, J=17.4 \mathrm{~Hz}, 1 \mathrm{H}), 5.33(\mathrm{~d}, J=11.1 \mathrm{~Hz}$, $1 \mathrm{H}), 5.15$ (s, 2H), 4.63 (d, J=5.6 Hz, 2H), 1.49 (s, 9H), 1.44 (s, 9H). ${ }^{13}$ C-NMR $\left(100 \mathrm{MHz}, \mathrm{CDCl}_{3}\right) \delta$ ppm 163.6, $156.7,156.3,156.0,152.9,136.8,133.7,129.8,128.9$, 128.7, 128.2, 127.7, 126.0, 120.9, 116.7, 111.6, 82.7, 79.0, 68.1, 40.6, 28.3, 28.0. LCMS (ESI) $m / z=504.1[\mathrm{M}+\mathrm{Na}]^{+}$, $482.1[\mathrm{M}+\mathrm{H}]^{+}$.

Boc-amidinourea derivative (11a) To a stirred solution of 9a (246.1 mg, $0.51 \mathrm{mmol})$ in dry THF (10 mL), a solution of linker $\mathbf{1 0}(\mathrm{N}$-(8-(allylamino)octyl)-2-phenylacetamide (261.0 mg, $0.82 \mathrm{mmol}$ ) in dry THF (5 mL) and freshly distilled dry TEA $(70 \mu \mathrm{L}, 0.51 \mathrm{mmol})$ were added dropwise under $\mathrm{N}_{2}$ atmosphere. The reaction mixture was stirred at reflux for $16 \mathrm{~h}$. After cooling, AcOEt was added, and the mixture was washed with water and brine. After drying over anhydrous $\mathrm{Na}_{2} \mathrm{SO}_{4}$, the mixture was filtered and evaporated in vacuo. The crude residue was purified by flash chromatography on silica gel, eluting with hexane/AcOEt 8:2 to give pure compound 11a. Yield: $73 \%$. ${ }^{1} \mathbf{H}-\mathbf{N M R}$ $\left(400 \mathrm{MHz}, \mathrm{CDCl}_{3}\right) \delta$ ppm $12.28(\mathrm{~s}, 1 \mathrm{H}), 8.41$ (s, 1H), 7.52 $(\mathrm{d}, J=7.5 \mathrm{~Hz}, 1 \mathrm{H}), 7.44(\mathrm{~d}, J=7.4 \mathrm{~Hz}, 1 \mathrm{H}), 7.35(\mathrm{~m}, 5 \mathrm{H})$, $7.32(\mathrm{~d}, J=6.9 \mathrm{~Hz}, 1 \mathrm{H}), 7.29(\mathrm{~d}, J=7.3 \mathrm{~Hz}, 2 \mathrm{H}), 7.25(\mathrm{~m}$, $1 \mathrm{H}), 7.02(\mathrm{~m}, 1 \mathrm{H}), 6.94(\mathrm{~d}, J=9.7 \mathrm{~Hz}, 2 \mathrm{H}), 5.77(\mathrm{~m}, 1 \mathrm{H})$, $5.66(\mathrm{~d}, J=16.4 \mathrm{~Hz}, 1 \mathrm{H}), 5.32$ (d, $J=10.8 \mathrm{~Hz}, 1 \mathrm{H}), 5.15$ $(\mathrm{s}, 2 \mathrm{H}), 5.09(\mathrm{~m}, 4 \mathrm{H}), 5.01(\mathrm{~d}, J=9.9 \mathrm{~Hz}, 1 \mathrm{H}), 4.55(\mathrm{dd}$, $J=14.8 \mathrm{~Hz}, 6.0 \mathrm{~Hz}, 2 \mathrm{H}), 4.05$ (d, $J=5.3 \mathrm{~Hz}, 1 \mathrm{H}), 3.89$ (d, $J=5.3 \mathrm{~Hz}, 1 \mathrm{H}), 3.36(\mathrm{t}, J=7.6 \mathrm{~Hz}, 1 \mathrm{H}), 3.21(\mathrm{t}, J=8.0 \mathrm{~Hz}$, $1 \mathrm{H}), 3.14(\mathrm{~m}, 2 \mathrm{H}), 1.51(\mathrm{~m}, 4 \mathrm{H}), 1.42(\mathrm{~s}, 9 \mathrm{H}), 1.21(\mathrm{~m}$, 8H). ${ }^{13} \mathbf{C}$-NMR (100 MHz, $\left.\mathrm{CDCl}_{3}\right) \delta$ ppm 163.7, 156.5, $154.1,153.9,153.3,135.3,134.7,133.7,129.3,129.0$, $128.7,128.6,128.4,128.4,128.0,127.8,126.8,126.0$, $120.7,116.7,115.5,111.5,81.9,68.1,66.5,50.5,48.5,47.5$, 45.7, 41.0, 40.1, 29.8, 29.4, 29.2, 28.5, 28.0, 27, 26.9, 26.6. LCMS (ESI) $m / z=748.9[\mathrm{M}+\mathrm{Na}]^{+}, 726.9[\mathrm{M}+\mathrm{H}]^{+}$.
Unsaturated macrocyclic amidinourea (12a) To a stirred solution of amidinourea derivative 9a $(247.1 \mathrm{mg}$, $0.34 \mathrm{mmol})$ in freshly degassed dry $\mathrm{CH}_{2} \mathrm{Cl}_{2}(170 \mathrm{~mL}$, $2 \mathrm{mM}$ solution), a solution of $2^{\text {nd }}$ generation Grubb's catalyst (58.0 mg, $0.2 \mathrm{mmol}$ ) in freshly degassed dry $\mathrm{CH}_{2} \mathrm{Cl}_{2}$ $(2 \mathrm{~mL})$ was added dropwise under $\mathrm{N}_{2}$ atmosphere. The reaction mixture was stirred at reflux for $16 \mathrm{~h}$. After cooling, the mixture was evaporated in vacuo. The crude residue was purified by flash chromatography on silica gel, eluting with hexane/AcOEt $85: 15$ to give macrocycle 12a. Yield: 75\%. ${ }^{1} \mathbf{H}$-NMR (400 MHz, $\mathrm{CDCl}_{3}$ ) $\delta$ ppm 12.27 (bs, 1H), $8.40(\mathrm{~m}, 1 \mathrm{H}), 7.58(\mathrm{~d}, J=8.0 \mathrm{~Hz}, 1 \mathrm{H}), 7.32(\mathrm{~m}, 6 \mathrm{H}), 7.23$ $(\mathrm{m}, 3 \mathrm{H}), 6.98(\mathrm{~m}, 3 \mathrm{H}), 6.58(\mathrm{~d}, J=15.6 \mathrm{~Hz}, 1 \mathrm{H}), 6.16(\mathrm{dt}$, $J=15.6 \mathrm{~Hz}, 5.2 \mathrm{~Hz}, 1 \mathrm{H}), 5.15$ (s, 2H), 5.08 (s, 2H), 4.69 (bs, $1 \mathrm{H}), 4.61(\mathrm{~d}, J=6.4 \mathrm{~Hz}, 2 \mathrm{H}), 3.92(\mathrm{~d}, J=5.2 \mathrm{~Hz}, 2 \mathrm{H}), 3.35$ $(\mathrm{t}, J=7.6 \mathrm{~Hz}, 2 \mathrm{H}), 3.16(\mathrm{~m}, 2 \mathrm{H}), 1.57(\mathrm{~s}, 4 \mathrm{H}), 1.46(\mathrm{~m}, 9 \mathrm{H})$, 1.23 (s, 8H). ${ }^{13} \mathrm{C}$-NMR $\left(100 \mathrm{MHz}, \mathrm{CDCl}_{3}\right) \delta \mathrm{ppm} \mathrm{163.7,}$ 155.3, 154.2, 153.6, 138.1, 137.8, 136.9, 129.6, 129.4, $129.1,128.8,128.7,128.3,126.5,122.9,118.6,99.9,82.2$, 72.2, 66.5, 45.1, 44.1, 43.4, 40.9, 31.1, 29.3, 29.2, 28.5, 27.3. LCMS (ESI) $m / z=698.2[\mathrm{M}+\mathrm{H}]^{+}$.

DiBoc-guanidino macrocyclic amidinourea (13a) To a stirred solution of $\mathbf{1 0 a}(180.2 \mathrm{mg}, 0.17 \mathrm{mmol})$ in isopropanol (19 mL), Pd/C 10\% (32.0 mg, $0.03 \mathrm{mmol})$ and a few drops of glacial AcOH were added. The reaction mixture was subject to three cycles of vacuo followed by a flush of $\mathrm{H}_{2}$ before being stirred under $\mathrm{H}_{2}$ ( $1 \mathrm{~atm}$ ) for $4 \mathrm{~h}$. Then, the mixture was filtered through a plug of celite, and the filtrate was evaporated in vacuo. The crude product was used directly in the next step without any further purification. LCMS (ESI) $m / z=566.3[\mathrm{M}+\mathrm{H}]{ }^{+}$. To a stirred solution of the crude in dry THF $(4.5 \mathrm{~mL})$, a solution of the crotyl guanylating agent $(N, N$ '-Di-Boc-(E)- $N$-crotyl$1 H$-pyrazole-1-carboximidamide, $60.0 \mathrm{mg}, 0.17 \mathrm{mmol})$ in dry THF $(2.8 \mathrm{~mL})$ and dry DIPEA $(89 \mu \mathrm{L}, 0.51 \mathrm{mmol})$ were subsequently added under $\mathrm{N}_{2}$ atmosphere. The reaction mixture was stirred at reflux for $12 \mathrm{~h}$. After cooling, the mixture was evaporated in vacuo and the residue was dissolved in AcOEt, washed with water twice and brine. After drying over anhydrous $\mathrm{Na}_{2} \mathrm{SO}_{4}$, the mixture was filtered, and evaporated in vacuo. The crude residue was purified by flash chromatography on silica gel, eluting with hexane/AcOEt 8:2 to give pure compound 13a. Yield: $52 \%$ over two steps. ${ }^{\mathbf{1}} \mathbf{H}-\mathbf{N M R}\left(400 \mathrm{MHz}, \mathrm{CDCl}_{3}\right)$ $\delta$ ppm $12.20(\mathrm{~s}, 1 \mathrm{H}), 8.54(\mathrm{~s}, 1 \mathrm{H}), 7.37(\mathrm{~d}, J=7.5 \mathrm{~Hz}$, 1H), $7.31(\mathrm{~m}, 1 \mathrm{H}), 7.26(\mathrm{~s}, 1 \mathrm{H}), 7.23(\mathrm{~d}, J=6.7 \mathrm{~Hz}, 1 \mathrm{H})$, $7.20(\mathrm{~d}, J=7.5 \mathrm{~Hz}, 1 \mathrm{H}), 6.99(\mathrm{~d}, J=7.8 \mathrm{~Hz}, 1 \mathrm{H}), 6.95(\mathrm{~d}$, $J=7.5 \mathrm{~Hz}, 1 \mathrm{H}), 6.83(\mathrm{~m}, 1 \mathrm{H}), 5.65(\mathrm{~m}, 1 \mathrm{H}), 5.50(\mathrm{~m}, 1 \mathrm{H})$, $5.06(\mathrm{~s}, 2 \mathrm{H}), 4.57(\mathrm{~d}, J=6.3 \mathrm{~Hz}, 2 \mathrm{H}), 4.15(\mathrm{~d}, J=5.4 \mathrm{~Hz}$, 2H), $3.18(\mathrm{~m}, 6 \mathrm{H}), 2.53(\mathrm{~m}, 2 \mathrm{H}), 1.97(\mathrm{~m}, 2 \mathrm{H}), 1.65(\mathrm{~d}$, $J=5.8 \mathrm{~Hz}, 3 \mathrm{H}), 1.48(\mathrm{~m}, 31 \mathrm{H}), 1.29(\mathrm{~s}, 8 \mathrm{H}) .{ }^{13} \mathbf{C}-\mathbf{N M R}$

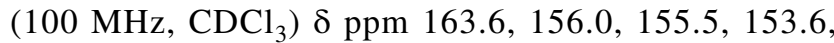
$153.3,142.7,134.0,130.7,129.9,129.7,128.9$, 127.7, 
127.4, 126.5, $126.1125 .8,120.6,110.6,82.9,82.1,79.1$, $69.4,60.3,49.9,47.3,40.9,38.1,30.8,30.2,29.6,29.3$, $29.2,28.9,28.7,28.2,28.1,28.0,27.0,26.8,20.9,17.1$. LCMS (ESI) $m / z=884.3[\mathrm{M}+\mathrm{Na}]^{+}, 862.4[\mathrm{M}+\mathrm{H}]^{+}$.

Guanidino macrocylic amidinourea trifluoroacetate salt (2a) To a stirred solution of 13a $(10.0 \mathrm{mg}$, $0,014 \mathrm{mmol})$ in dry $\mathrm{CH}_{2} \mathrm{Cl}_{2}(1.7 \mathrm{~mL})$, freshly distilled TFA $(300 \mu \mathrm{L}$, final concentration $10 \% \mathrm{v} / \mathrm{v})$ was added dropwise. The reaction mixture was stirred at r.t. for $12 \mathrm{~h}$. The mixture was evaporated in vacuo. Then, it was treated with toluene and methanol and evaporated in vacuo to remove TFA residue. The crude was treated with $\mathrm{Et}_{2} \mathrm{O}$ and hexane and then decanted, and the solvents were pipetted off. This procedure was repeated several times to yield compound 2a. Yield: $99 \% .{ }^{1} \mathbf{H}-\mathbf{N M R}\left(400 \mathrm{MHz}, \mathrm{CD}_{3} \mathrm{OD}\right)$ $\delta \mathrm{ppm} 7.45(\mathrm{~d}, J=6.9 \mathrm{~Hz}, 1 \mathrm{H}), 7.36(\mathrm{~d}, J=5.6 \mathrm{~Hz}, 2 \mathrm{H})$, $7.27(\mathrm{dd}, J=17.5 \mathrm{~Hz}, 7.6 \mathrm{~Hz}, 1 \mathrm{H}), 7.21(\mathrm{~d}, J=8.0 \mathrm{~Hz}$, $1 \mathrm{H}), 7.08(\mathrm{dd}, J=11.7 \mathrm{~Hz}, 6.5 \mathrm{~Hz}, 1 \mathrm{H}), 7.07(\mathrm{~m}, 1 \mathrm{H})$, $6.86(\mathrm{~d}, J=8.9 \mathrm{~Hz}, 1 \mathrm{H}), 5.73(\mathrm{~m}, 1 \mathrm{H}), 5.49(\mathrm{~m}, 1 \mathrm{H}), 5.07$ $(\mathrm{s}, 2 \mathrm{H}), 4.43(\mathrm{~m}, 2 \mathrm{H}), 3.74(\mathrm{~d}, J=5.4 \mathrm{~Hz}, 2 \mathrm{H}), 3.39(\mathrm{~m}$, $1 \mathrm{H}), 3.28(\mathrm{~d}, J=12.8 \mathrm{~Hz}, 1 \mathrm{H}), 3.15(\mathrm{t}, J=7.1 \mathrm{~Hz}, 2 \mathrm{H})$, $2.82(\mathrm{~s}, 1 \mathrm{H}), 2.61(\mathrm{~s}, 1 \mathrm{H}), 2.09(\mathrm{~m}, 1 \mathrm{H}), 1.85(\mathrm{~m}, 1 \mathrm{H})$, $1.70(\mathrm{~d}, J=6.4 \mathrm{~Hz}, 3 \mathrm{H}), 1.55(\mathrm{~m}, 6 \mathrm{H}), 1.31(\mathrm{~m}, 8 \mathrm{H}) .{ }^{13} \mathrm{C}-$ NMR $\left(100 \mathrm{MHz}, \mathrm{CD}_{3} \mathrm{OD}\right) \delta \mathrm{ppm} 157.4,155.0,152.0$, $131.2,131.1,130.8,130.1,129.6,127.2,127.0,126.4$ $125.4,124.1,122.5,122.0,121.0,117.1,116.3,113.4$, 85.9, 79.3, 44.0, 42.5, 30.7, 30.3, 30.2, 30.0, 27.6, 17.8 . LCMS (ESI) $m / z=584.4[\mathrm{M}+\mathrm{Na}]^{+}, 562.3[\mathrm{M}+\mathrm{H}]^{+}$, $281.7[\mathrm{M}+2 \mathrm{H}]^{2+}$.

Procedures and characterizations for final compounds $2 \mathrm{~b}-\mathrm{g}$ and their intermediates $(3-13 \mathrm{~b}-\mathrm{g}$ and 14-15) are reported in Supporting Information.

\section{Antifungal activity testing}

Yeast cells were grown in yeast peptone dextrose (YPD) medium at $37^{\circ} \mathrm{C}$ for $16 \mathrm{~h}$ and $150 \mathrm{rpm}$ orbital shaker. Cells were then sub-inoculated in fresh YPD medium and grown to an optical density of 0.3 . The turbidity of the inoculum was adjusted to $0.5 \mathrm{McF}$ arland and diluted 1:500 in RPMI 1640 broth, corresponding to around $2.5 \times 10^{5} \mathrm{CFU} / \mathrm{mL}$. MICs were determined by liquid growth inhibition assays by Clinical and Laboratory Standards Institute (CLSI) guidelines, using serial dilutions of the compounds dissolved in an appropriate buffer with a final concentration ranging from 256 to $0.125 \mu \mathrm{g} / \mathrm{mL}$ in a 96 -well flatbottomed microtiter plate [30]. Plates were incubated at $35{ }^{\circ} \mathrm{C}$, and MICs were visualized after $24 \mathrm{~h}$ as the lowest concentration of the tested compound that completely inhibited cell growth.

\section{MTT assay}

All chemicals were purchased from Euroclone (Milan, Italy). In vitro cytotoxicity on normal human dermal fibroblasts, purchased from American Type Culture Collection (ATCC) (Manassas, VA). Cells were cultured in Dulbecco's modified Eagle's medium (DMEM), supplemented with $10 \%$ fetal bovine serum (FBS), $2 \mathrm{mM}$ L-glutamine, and 10,000 units $/ \mathrm{mL}$ penicillin/streptomycin at $37{ }^{\circ} \mathrm{C}$ in a $5 \% \mathrm{CO}_{2} \mathrm{v} / \mathrm{v}$ atmosphere. Briefly, $5 \times 10^{3}$ cells/well were plated in $0.2 \mathrm{~mL}$ of medium/well in 96-well plates, the day after seeding, a solution of the test compound in dimethyl sulfoxide (DMSO) $(0.1$ to $100 \mu \mathrm{g} / \mathrm{mL}$ ) was added and incubated for 24 and $48 \mathrm{~h}$ at $37{ }^{\circ} \mathrm{C}$ in $5 \% \mathrm{v} / \mathrm{v} \mathrm{CO}_{2}$ atmosphere. After incubation, the medium was carefully removed and each well was washed with Dulbecco's phosphate-buffered saline (PBS) twice and $150 \mu \mathrm{L}$ of 3-(4,5-dimethylthiazol-2-yl)-2,5-diphenyltetrazolium bromide (MTT) $(5 \mathrm{mg} / \mathrm{mL})$ in Minimum Essential Medium (MEM) were added. The plates were incubated for $3 \mathrm{~h}$ in a $5 \% \mathrm{v} / \mathrm{v} \mathrm{CO}_{2}$ atmosphere. After incubation, 100 $\mu \mathrm{L}$ of isopropanol were added to each well and plates were shaken at r.t. for $30 \mathrm{~min}$. The optical density was measured by a microtiter plate reader (Multiskan SkyHigh Microplate Spectrophotometer, Thermo Fisher, Italy) at $570 \mathrm{~nm} . \mathrm{CC}_{50}$ values were calculated by GraphPad Prism 6.0 software using the best fitting sigmoid curve. For each compound, the determination was performed in triplicate.

\section{PAMPA experiments}

$\mathrm{P}_{\text {app }}$ values of the tested compounds were evaluated as previously reported.[31] Briefly, for each compound, a donor solution was prepared from a stock solution of the test compound in DMSO $(1 \mathrm{mM})$ diluted with PBS $(\mathrm{pH} 7.4$, $25.0 \mathrm{mM}$ ) to a final concentration of $500 \mu \mathrm{M}$. Donor wells were filled with $150 \mu \mathrm{L}$ of the donor solution. Filters were coated with $5 \mu \mathrm{L}$ of a $1 \%$ w/v phosphatidylcholine (L- $\alpha$ phosphatidylcholine egg yolk, Type XVI-E, purchased from Merck) in dodecane solution and the lower wells were filled with $300 \mu \mathrm{L}$ of the acceptor solution (DMSO/PBS 1:1). The sandwich plate was assembled and incubated at r.t. for $5 \mathrm{~h}$ under gentle agitation. After the incubation time, the sandwich was disassembled and the amount of compound in each donor and acceptor wells was measured by the LC-UV-MS protocol. For each compound, the determination was performed in three independent experiments. $\mathrm{P}_{\text {app }}$ and MR\% values were calculated as reported $[32,33]$.

\section{Determination of pan-assay interference compounds}

The behavior of all the tested compounds (2a-g) as pan-assay interference compounds (PAINS) was examined through 
prediction by the web tools SwissADME [24, 34] and false positive remover, and no alert of PAINS was recorded.

\section{Supplementary Information}

The online version contains supplementary material available at and contains the following paragraphs: Preparation of compound $\mathbf{2 g}$. Chemical procedures and characterizations for final compounds $\mathbf{2} \mathbf{b}-\mathbf{g} ;{ }^{1} \mathrm{H}$ and ${ }^{13} \mathrm{C}$ NMR spectra of some derivatives as representatives of the series.

Supplementary information The online version contains supplementary material available at https://doi.org/10.1007/s11030-022-10388-7.

Acknowledgements We thank LDS (Lead Discovery Siena) S.r.l. for financial support.

Author contributions L.J.I.B., I.D., A.C., D.D., G.I.T., and F.O. synthesized and characterized the compounds. R.M. and M.M. performed the biological assays. E.R. performed PAMPA experiments. C.V. performed cytotoxicity experiments. L.J.I.B., I.D., M.S., F.B., L.B., and E.D. analyzed data. L.J.I.B. and I.D. wrote the manuscript. All authors approved the final version of the manuscript.

\section{Declarations}

Conflicts of interest. The authors declare that there is no conflict of interest.

\section{References}

1. Kainz K, Bauer MA, Madeo F, Carmona-Gutierrez D (2020) Fungal infections in humans: the silent crisis. Microb. cell 7:143-145. https://doi.org/10.15698/mic2020.06.718

2. Li Y, Gao Y, Niu X et al (2020) A 5-year review of invasive fungal infection at an academic medical center. Front Cell Infect Microbiol 10:553648. https://doi.org/10.3389/fcimb.2020.553648

3. Bongomin F, Gago S, Oladele RO, Denning DW (2017) Global and multi-national prevalence of fungal diseases - estimate precision. J Fungi 3(4):57. https://doi.org/10.3390/jof3040057

4. Limper AH, Adenis A, Le T, Harrison TS (2017) Fungal infections in HIV/AIDS. Lancet Infect Dis 17:e334-e343. https://doi. org/10.1016/S1473-3099(17)30303-1

5. Höfs S, Mogavero S, Hube B (2016) Interaction of Candida albicans with host cells: virulence factors, host defense, escape strategies, and the microbiota. J Microbiol 54:149-169. https://doi.org/ 10.1007/s12275-016-5514-0

6. Pathakumari B, Liang G, Liu W (2020) Immune defence to invasive fungal infections: a comprehensive review. Biomed Pharmacother 130:110550. https://doi.org/10.1016/j.biopha.2020.110550

7. Cataldo MA, Tetaj N, Selleri M et al (2020) Incidence of bacterial and fungal bloodstream infections in COVID-19 patients in intensive care: an alarming "collateral effect." J Glob Antimicrob Resist 23:290-291. https://doi.org/10.1016/j.jgar.2020.10.004

8. Rawson TM, Moore LSP, Zhu N et al (2020) Bacterial and fungal coinfection in individuals with coronavirus: a rapid review to support COVID-19 antimicrobial prescribing. Clin Infect Dis 71(9):2459-2468. https://doi.org/10.1093/cid/ciaa530
9. Song G, Liang G, Liu W (2020) Fungal co-infections associated with global COVID-19 pandemic: a clinical and diagnostic perspective from China. Mycopathologia 185:599-606. https://doi. org/10.1007/s11046-020-00462-9

10. Fernández-García R, de Pablo E, Ballesteros MP, Serrano DR (2017) Unmet clinical needs in the treatment of systemic fungal infections: the role of amphotericin B and drug targeting. Int J Pharm 525:139-148. https://doi.org/10.1016/j.ijpharm.2017.04. 013

11. Brown GD, Denning DW, Gow NARR et al (2012) Hidden killers: human fungal infections. Sci Transl Med 4(165):165rv13. https:// doi.org/10.1126/scitranslmed.3004404

12. Seyoum E, Bitew A, Mihret A (2020) Distribution of Candida albicans and non-albicans Candida species isolated in different clinical samples and their in vitro antifungal suscetibity profile in Ethiopia. BMC Infect Dis 20:231. https://doi.org/10.1186/ s12879-020-4883-5

13. Posteraro B, Sanguinetti M, Fiori B et al (2006) Caspofungin activity against clinical isolates of azole cross-resistant Candida glabrata overexpressing efflux pump genes. J Antimicrob Chemother 58:458-461. https://doi.org/10.1093/jac/dk1237

14. Gabaldón T, Gómez-Molero E, Bader O (2020) Molecular typing of Candida glabrata. Mycopathologia 185:755-764. https://doi. org/10.1007/s11046-019-00388-x

15. Perlin DS, Rautemaa-Richardson R, Alastruey-Izquierdo A (2017) The global problem of antifungal resistance: prevalence, mechanisms, and management. Lancet Infect Dis 17:e383-e392. https:// doi.org/10.1016/S1473-3099(17)30316-X

16. Lin YY, Shiau S, Fang CT (2015) Risk factors for invasive Cryptococcus neoformans diseases: a case-control study. PLoS ONE 10(3):e0119090. https://doi.org/10.1371/journal.pone.0119090

17. Roemer T, Krysan DJ (2014) Unmet clinical needs, and new approaches. Cold Spring Harb Perspect Med 4:a019703

18. Shaw KJ, Ibrahim AS (2020) Fosmanogepix: a review of the firstin-class broad spectrum agent for the treatment of invasive fungal infections. J Fungi 6(4):239. https://doi.org/10.3390/jof6040239

19. Manetti F, Castagnolo D, Raffi F et al (2009) Synthesis of new linear guanidines and macrocyclic amidinourea derivatives endowed with high antifungal activity against Candida spp. and Aspergillus spp. J Med Chem 52(23):7376-7379. https://doi.org/10.1021/ jm900760k

20. Sanguinetti M, Sanfilippo S, Castagnolo D et al (2013) Novel macrocyclic amidinoureas: potent non-azole antifungals active against wild-type and resistant Candida species. ACS Med Chem Lett 4:852-857. https://doi.org/10.1021/ml400187w

21. Deodato D, Maccari G, De Luca F et al (2016) Biological characterization and in vivo assessment of the activity of a new synthetic macrocyclic antifungal compound. J Med Chem 59:3854-3866. https://doi.org/10.1021/acs.jmedchem.6b00018

22. Orofino F, Truglio GI, Fiorucci D et al (2020) In vitro characterization, ADME analysis, and histological and toxicological evaluation of BM1, a macrocyclic amidinourea active against azoleresistant Candida strains. Int J Antimicrob Agents 55:105865. https://doi.org/10.1016/j.ijantimicag.2019.105865

23. Maccari G, Deodato D, Fiorucci D et al (2017) Design and synthesis of a novel inhibitor of $T$. Viride chitinase through an in silico target fishing protocol. Bioorg Med Chem Lett 27:3332-3336. https://doi.org/10.1016/j.bmcl.2017.06.016

24. Daina A, Michielin O, Zoete V (2017) SwissADME: a free web tool to evaluate pharmacokinetics, drug-likeness and medicinal chemistry friendliness of small molecules. Sci Rep 71(7):1-13. https://doi.org/10.1038/srep42717

25. Ding R, He Y, Wang X et al (2011) Treatment of alcohols with tosyl chloride does not always lead to the formation of tosylates. Molecules 16:5665-5673. https://doi.org/10.3390/molecules1 6075665 
26. Pasero C, D’Agostino I, De Luca F et al (2018) Alkyl-guanidine compounds as potent broad-spectrum antibacterial agents: chemical library extension and biological characterization. J Med Chem. https://doi.org/10.1021/acs.jmedchem.8b00619

27. Zamperini C, Maccari G, Deodato D et al (2017) Identification, synthesis and biological activity of alkyl-guanidine oligomers as potent antibacterial agents. Sci Rep 7:8251. https://doi.org/10. 1038/s41598-017-08749-6

28. D'Agostino I, Ardino C, Poli G, et al (2022) Antibacterial alkylguanidino ureas: Molecular simplification approach, searching for membrane-based MoA. Eur J Med Chem 114158. https://doi.org/ 10.1016/J.EJMECH.2022.114158

29. Miel H, Rault S (1998) Conversion of N, N'-bis(tert-butoxycarbonyl)guanidines to $\mathrm{N}$-(N'-tert-butoxycarbonylamidino)ureas. Tetrahedron Lett 39(12):1565-1568. https://doi.org/10.1016/ S0040-4039(98)00025-2

30. CLSI (2017) Reference method for broth dilution antifungal susceptibility testing of yeasts. 4st ed. CLSI guideline M27. Clinical and Laboratory Standards Institute, Wayne, PA

31. Rango E, D'Antona L, Iovenitti G et al (2021) Si113-prodrugs selectively activated by plasmin against hepatocellular and ovarian carcinoma. Eur J Med Chem 223:113653. https://doi.org/10. 1016/j.ejmech.2021.113653

32. Wohnsland F, Faller B (2001) High-throughput permeability $\mathrm{pH}$ profile and high-throughput alkane/water $\log \mathrm{P}$ with artificial membranes. J Med Chem 44:923-930. https://doi.org/10.1021/ jm001020e

33. Sugano K, Hamada H, Machida M, Ushio H (2001) High throughput prediction of oral absorption: improvement of the composition of the lipid solution used in parallel artificial membrane permeation assay. J Biomol Screen 6:189-196. https://doi.org/10.1177/ 108705710100600309

34. Baell JB, Holloway GA (2010) New substructure filters for removal of pan assay interference compounds (PAINS) from screening libraries and for their exclusion in bioassays. J Med Chem 53:2719-2740. https://doi.org/10.1021/jm901137j

Publisher's Note Springer Nature remains neutral with regard to jurisdictional claims in published maps and institutional affiliations.

\section{Authors and Affiliations}

\section{Lorenzo J. I. Balestri ${ }^{1}$. Ilaria D'Agostino ${ }^{1}$ (1) Enrico Rango ${ }^{1}$. Chiara Vagaggini ${ }^{1} \cdot$ Rosalba Marchitiello ${ }^{2}$. Melinda Mariotti ${ }^{2} \cdot$ Alexandru Casian $^{1}$ - Davide Deodato ${ }^{1}$. Giuseppina I. Truglio ${ }^{1}$. Francesco Orofino ${ }^{1}$. Maurizio Sanguinetti ${ }^{2,3} \cdot$ Francesca Bugli $^{2,3} \cdot$ Lorenzo Botta $^{4,5} \cdot$ Elena Dreassi ${ }^{1}$ (C)}

1 Department of Biotechnology, Chemistry and Pharmacy, University of Siena, 53100 Siena, Italy

2 Dipartimento Di Scienze Biotecnologiche Di Base, Cliniche Intensivologiche E Perioperatorie, Università Cattolica del Sacro Cuore, Rome, Italy

3 Dipartimento Di Scienze Di Laboratorio E Infettivologiche, Fondazione Policlinico Universitario A. Gemelli IRCCS, Rome, Italy
4 Lead Discovery Siena S.R.L, Via Vittorio Alfieri 31, 53019 Castelnuovo Berardenga, Italy

5 Department of Ecological and Biological Sciences, University of Tuscia, Largo Università S.N.C, 01100 Viterbo, Italy 